\title{
DEVELOPMENT OF HISTORY OF EDUCATION \\ IN THE CONTEXT OF TEACHER TRAINING IN UNIVERSITIES: THE CASE OF LATVIA AND BELGIUM
}

\author{
Iveta Kestere, Iveta Ozola \\ University of Latvia
}

\begin{abstract}
The aim of this study is to seek answers to the following questions: 1) How has the formation and development of the history of education interacted with teacher training in universities? 2) How did the Iron Curtain influence the development of the history of education in Latvia and how can the consequences of Soviet era in the history of education be overcome? 3) What kind of history of education is suitable for teacher training programmes today? These questions are researched based on the analysis of the history of pedagogy as a course in Latvian and Belgian universities.

KEY WORDS: history of pedagogy, revisionism in the history of pedagogy, "new" history of education, teacher training, study process in universities, comparative approach, Iron Curtain.
\end{abstract}

\begin{abstract}
Anotacija
Moksliniu tyrimu siekiama atsakyti i klausimus, kaip švietimo istorijos formavimasis ir raida sąveikavo su mokytojų rengimu universitetuose; kaip geležinė uždanga paveikė švietimo istorijos raidą Latvijoje ir kaip galima įveikti sovietinès eros pasekmes švietimo istorijoje. Švietimo istorija neturètų tarnauti tik kai kurių pedagoginių teorijų ir sistemų įteisinimui. Esame įsitikinę, kad modernus, problema paremtas švietimo istorijos mokslinis tyrimas praturtina mokytojų rengimo mokymo programą pamąstymais ir pasvarstymais apie reikšmingus klausimus ir reiškinius visose švietimo bei visuomenès gyvenimo srityse.

PAGRINDINIAI ŽODŽIAI: pedagogikos istorija, revizionizmas pedagogikos istorijoje, „nauja“ švietimo istorija, mokytojų rengimas, studijų procesas universitetuose, lyginamasis požiūris, geležinė uždanga.
\end{abstract}

\section{Introduction}

The question "What a teacher should know?" has been topical at all times. Politicians and theoreticians, as well as practitioners and parents have discussed this problem. Historians of education, whose job traditionally has been connected with teacher training, also have an opinion. As the name indicates, the history of education, or pedagogy (as it is accepted in the Baltic countries), combines two sciences - education / pedagogy and history. However, if the question regarding pedagogy as a study subject in teacher training is "What should it be like?", then the question for the history of pedagogy should be "To be or not to be?" (Depaepe, 2008 , p. 5). And if it is "to be", then what have the historians of pedagogy been able, and are able, to offer to teacher training programs? The aim of our study is to reveal how the history of education / pedagogy was formed and developed in interaction with teacher training in universities, how the Iron Curtain influenced 
the development of history of education in Latvia and how the consequences of Soviet era could be overcome, as well as what kind of history of education should be embedded into teacher training curriculum today.

The consequences of the years spent under the totalitarian regime of the Soviet Union have been much discussed in the Baltic countries after regaining independence. The currently very popular and generally negative opinion about this era is connected with the intellectual isolation that lasted for decades, when the Iron Curtain separated the Soviet republics from the democratic world. However, how should one understand whether the modern situation is the consequence of the occupation, or should its roots be sought in a more ancient past? Or is it the contrary - is it due to the events of the modern world? The answers to these questions can be found by applying the comparative approach, which offers possibilities for abstraction and for revealing peculiarities and generalizations (Haupt, Kocka, 2004).

When researching the development of the history of pedagogy as a university subject in Soviet Latvia, we used Belgium for comparison. The comparison of these countries is untraditional, because neither is considered a superpower in the study of the history of pedagogy, as are, for example, the USA, Great Britain, France, or Germany. They also do not share a common language or political history. Nevertheless, this dissimilar context is challenging. If we are able to find commonalities in the teaching of the history of pedagogy in these countries, then, perhaps, it reflects the trends of the $20^{\text {th }}$ century in the world and reveals the most characteristic features of the development of the history of pedagogy. However, both countries have been in the crossroads of super powers, and the education models of these two countries reflect different influences, thus making them a peculiar quintessence of epochal trends. As Crook and McCulloch (2002) admit, a "significant outcome of developing comparative approaches to the history of education should be in enhancing our understanding of influences and interactions" (p. 398).

In order to compare the development of history of pedagogy at the Universities of Latvia and Leuven, course literature and the curricula of the history of pedagogy were mainly used as historical sources for this study: They are used to compare the main topics of study and outstanding pedagogues, as well as expressions of ideology.

The background of history of education as the teaching/learning subject. Pedagogy as a subject in teacher education appeared with the first professional teacher education institutions - teacher seminars or colleges (Campbell, Sherington, 2002, p. 49) - the mass emergence of which can be dated in the first half of the $19^{\text {th }}$ century. Such educational institutions in the territory of Latvia were first established in the 1840s. However, the first record of the history of pedagogy 
as the a subject can be found only in the regulations published in 1870 on teacher seminars in Riga and other teaching administrative regions. The regulations state that becoming acquainted with the history of education in the subject "Basics of pedagogy" is desirable, but not compulsory (Faljbork, Cjarnolusky, 1901, p. 43). As sources show, this recommendation was fulfilled in the teacher seminars in the territory of Latvia. One of the topics in the subject "School studies" (Die Schulkunde) in 1879 was "The history of folk schools from Luther until today" (Lehrplan für..., 1879, p. 12). In 1903 the topic "A short history of schools in Russia" was included in the subject "Pedagogy" (Tomāss, 1940, p. 100).

Certainly, the history of pedagogy in the territory of Latvia, as it was in other countries of Europe at this time, was fully subjected to utilitarian aims - inspiring future teachers with the help of the past, as well as ensuring the course of general pedagogy with ideas and concepts (Depaepe, 2012, p. 464). Regardless of its quality, it should be noted that the presence of the history of pedagogy in teacher training institutions influenced both teacher training and the history of pedagogy as a science.

Why is teaching the history of pedagogy so important? The acquisition of theoretical knowledge has always been considered an indicator of the quality of "good" education in the history of humanity. Without theoretical knowledge, the employee is only an artisan. The history of pedagogy is one of the theoretical subjects that takes teacher education to a higher level. As Beales (1989) points out, "Only when the Victorian public ceased to regard its elementary school teachers as primarily craftsmen, as artisans with a veneer of culture, could the training of these teachers take on a new dimension and their vocation be appreciated as that not only of teacher but of educator" (p. 131).

However, this process is reciprocal - teacher education develops educational sciences, including the history of pedagogy (Ķestere, Ozola, 2011). This has several confirmations, one of which is that the introduction of the history of pedagogy as a subject encourages the writing textbooks and this, certainly, promotes the formation of theoretical ideas. Friedrich Wilhelm Schütze (1807-1888) devoted 125 pages to the history of schools, describing the historic development from Luther on (Schütze, 1879). This was used as a textbook in teacher seminars in the territory of Latvia.

One of the indicators characterizing the formation of science (including the history of pedagogy) is the level at which the discipline is being taught (Depaepe, 1993b, p. 3). Does it take place in general comprehensive school, university, adult educational courses, or elsewhere? Thus, a qualitatively new stage in the development of history of pedagogy began when it entered the universities where professors of pedagogy adopted it: "Once enshrined in university chairs, and with 
modern scholarship in the 'pure' subjects to draw upon and adapt to Professional end, Education began to establish itself on a triple basis of theory: educational philosophy and principles, educational psychology, and the history of education from Plato onwards" (Beales, 1989, p. 131).

History of pedagogy in the interwar period (1920s-1930s). In comparison with other European countries (pedagogy in the universities of Germany had been taught since the first half of the $18^{\text {th }}$ century), pedagogy in higher education institutions of Latvia began to be taught relatively late, as there were no higher education institutions. The first humanities-type institutions (including university) were formed after the establishment of independent Latvia in 1918. However, from the very beginnings of the university, the history of pedagogy was singled out as a separate subject. The history of pedagogy in the universities of Belgium was introduced some 20 years earlier in 1890 (Coetzer, 1993, p. 6). In comparison, at the University of London, the history of pedagogy was taught only as part of educational sciences from 1912 until 1932 (Beales, 1989, p. 133).

The history of pedagogy as a separate subject is mentioned for the first time in 1919 in the temporary curriculum of the University of Latvia Department of Pedagogy at the Faculty of Philology and Philosophy (Latvijas universitāte..., 1939, p. 181). In 1934, the course History of Latvian Education and Schools, in some sources mentioned as History of Latvian Pedagogy, was also taught (LVVA, 7427.f., 6.apr., 63.1., p. 220).

The first to teach the history of pedagogy course at the University of Latvia in 1920/1921 was Jānis Kauliņš (1863-1940) - one of the first academically educated Latvian philologists, honorary doctor of philology, graduate of Tartu University, and professor since 1931. Besides teaching the history of pedagogy and History of Latvian education and schools, Kaulinş̌ also taught courses in foreign language teaching methods, classical languages and the Latvian language. For a shorter period of time, he also taught other subjects and led seminars in pedagogy (Ķestere, 2007).

It is interesting to note that the history of pedagogy at the University of Leuven was taught from 1927 until 1949 by professor Jan Baptist Gessler (1878-1952), a doctor of classic philology, who also taught courses on general methods of teaching, methods of teaching classical and modern languages, Latin, and folklore. $\mathrm{He}$, in turn, was a pioneer, who was the first to teach courses on pedagogy at the University of Leuven in Dutch (studies were mainly in French) (Verheyen, 1939, p. 543; M.A.N., 1977, p. 176).

In the autumn of 1934, the prominent Latvian philosopher Pauls Jurēvičs (1891-1981), replaced Kaulinšs and began to teach the history of pedagogy. He was a graduate of the Faculty of History and Philology at Tartu University. In 1935 
Jurēvičs was elected professor, both in the history of pedagogy and philosophy (LVVA, 7427.f., 13.apr., p.719). Jurēvičs was primarily interested in philosophy, and it seems that because of this, soon the history of pedagogy was taught by another lecturer.

Certainly, the classical philological education of the above-mentioned professors influenced the content of the history of pedagogy course and methods of delivery. Assigning the teaching of the history of pedagogy course to philologists reveals the view of the history of pedagogy in the 1920s and 1930s. Richardson (1999) describes the history of education as consisting of the history of the pedagogical thought (ideas, theories), which was methodologically closely connected with philosophy and philology, as well as the history of educational institutions (schools, higher education institution, teacher seminars, etc.), which described facts in chronological order. Campbell and Scherington (2002), too, emphasize philosophy as a natural partner of the history of education (p. 46-47).

Indeed, the students of the universities of Leuven and Latvia mastered the history of pedagogy as a humanitarian subject, along with philosophy and philology. Unfortunately, the scope of material to be compared is rather different. One can find Gessler's 76-page typed syllabus for the history of pedagogy for 1934/1935 in the University of Leuven library (Katholieke Universiteit..., 1934-1945). As regards the teaching of the history of pedagogy at the University of Latvia, Jurēvičs and Kauliņšs' syllabi for the same academic year are hand-written and contain no more than two pages (LVVA, 7427.f., 6.apr., 63.1.). This very different scope is characteristic in later years as well: In Leuven the syllabi resemble thick books, but in Latvia they are small booklets containing no more than 20 pages.

Several books on the history of pedagogy were published in Belgium during the interwar period. Dutch pedagogue Godfried Frans Rombouts (1883-1962) published A Textbook in Historical Pedagogy (1929) with wonderful additional materials for the methods of teaching (Rombouts, 1929). In Latvia Krists Obšteins (1867-1952) published his History of Pedagogy in four volumes (Obšteins, 19291939) at the same time, but the first textbook in the history of pedagogy in Latvian was only published in 1943 (Seilšs, 1943). However, there is no reliable information indicating that Obšteins and Seil̦క̌s's books were used in the history of pedagogy studies at the University of Latvia.

Actually, there were no real differences in the syllabi of the University of Leuven and University of Latvia as regards the periodization of the history of pedagogy and the main topics including Hindu, Persian, Chinese, and Jewish upbringing, as well as education in Sparta, Athens, and Rome. They discussed cathedral schools and universities in the Middle Ages and the traditions of scholastics, as well as the influence of the Reformation, Counter-reformation and Jesuit schools. 
They analyzed different trends of pedagogy: humanism, pietism, naturalism, philanthropist, and the modern trends of the $20^{\text {th }}$ century.

However in Latvia, much less attention is paid to the activities of religious orders in education (this topic has still not been researched in Latvia), such as the Benedictines, Hieronymites, and Oratorians. There is still nothing known about the activities of the French Port-Royal in Latvia. Most likely, it was connected with the traditions of Catholicism in Belgium, which was unusual for protestant Latvia.

Differences in the syllabi are observed in the names of "great men" - philosophers and pedagogues. Certainly, in both you can find the classics, such as Socrates, Plato, Aristotle, Quintilian, Montaigne, Comenius, Rousseau, Pestalozzi, Spenser, Froebel, and Herbart. Latvia lacked the description of the activities of Charles Magne to whom Gessler devoted two pages in his syllabus, and there is no information about Rablais or de la Salle in Latvia. This seems to be a result of the close cultural links between Belgium and France, while the influence of French culture in German-oriented Latvia was not so pronounced. This leads to the conclusion that the dominant religion and influences of neighboring countries had a great impact on the choice of issues in the history of pedagogy.

History of pedagogy after World War II. Campbell and Scherington (2002) describe the history of pedagogy in the time period between the $1880 \mathrm{~s}$ and the 1950s as the "history of propaganda", the aim of which was to legitimize the existing system of education as a triumph, to "celebrate the presence", and to provide heroes (p. 50-52). Tyack (1976) concurs and writes that the task of history of pedagogy since the turn of the $20^{\text {th }}$ century has been to scientifically explain the origin and development of education and the current educational institutions as the culmination of progress (p. 4).

The Soviet Union had also accepted this view of the history of pedagogy with enthusiasm, because it allowed its use as one of the many types of media for legitimizing the existing system. It is clearly stated in the introduction of a textbook on the history of pedagogy: "The history of pedagogy has to show the historical importance of the Great October Socialist Revolution in upbringing and educational work, as well as the achievements not yet experienced in the history of mankind that have been gained in the field of the nation's education by the world's first socialist country of workers and peasants under the leadership of the All-union communist (Bolshevik) party, the party of Lenin and Stalin" (Gaņeļins, Golants, 1947, p. 7).

The history of pedagogy after World War II was treated as the source of inspiration for teachers. However, the practice of teaching the history of pedagogy was in contradiction to the aims that were worth praising. In reality history of pedagogy courses and textbooks were overloaded with "acts and facts" and it was boring. In 
1949 historian of pedagogy William Brickman wrote “...the textbook (...) in many cases, was a compilation of data derived from previously published textbooks" (Tyack, 1976, p. 5).

Considerable political changes have taken place in Latvia since World War II - the country was occupied by the Soviet Union and Latvia became one of the 15 Soviet republics. Education was centralized in the capital Moscow, and all syllabi and curricula, starting with elementary school up to higher education, were changed. Certainly, these changes also affected the history of pedagogy course.

Since the latter half of the 1940s, the history of pedagogy in the University of Latvia was taught by assistant professor Milda Drīzule (1895-1992), a graduate of the pedagogical courses of Moscow University Nr. 2 (Anspaks, 1998, p. 39).

Gessler continued teaching the history of pedagogy in the University of Leuven until 1949. The program compiled by him contained 116 pages and was published in 1948 (Gessler, 1948). The same year, the fourth edition of Rombouts textbook was also published (Rombouts, 1948).

A textbook on the history of world pedagogy in the Latvian language was published in 1947 (Ganeļins, Golants, 1947). This was a translation from the Russian; the authors of the book were two Russian pedagogues, Sholom Ganjeljin and Jevgenij Golant.

If we compare Gessler's syllabi with Ganjeljin and Golant's textbook, there were not many differences in the topics to be learned: The history of pedagogy covered ancient Egypt, Sparta, Athens, and Rome and in the Middle Ages cloister schools, the flourishing of scholastics, universities, and urban schools. Then came topics on the pedagogy of humanism, the Reformation, and the Jesuits. Also, the previously mentioned classics of pedagogy were discussed.

However, two distinct lines of development become visible: 1) the connection between pedagogy and religion in Belgium and 2) the connection between pedagogy and the class structure of society in the Soviet Union. In Gessler's (1948) syllabus we find such topics as "Catechism of the church fathers" (p. 114) and "Two Catholic educators" (p. 116). From the very first pages, the textbook by Ganjeljin and Golant traces the development of education in the context of class society, where the good one is "working class" and the bad one "bourgeois". The following topics can be also found: "The workers' demands in the field of education" and "Bourgeois pedagogy at the end of the $19^{\text {th }}$ century and beginning of the $20^{\text {th }}$ century" (Gañelins, Golants, 1947, p. 115, 197).

We have to agree with Campbell and Scherington (2002) who state that the objective of the history of pedagogy to offer heroes. Both in Belgium and in Soviet Latvia this was a well-performed task. The hero of pedagogues at the University of Leuven was a clergyman-pedagogue; in Latvia he was the fighter for the victory 
of socialism/communism. In Ganjeljin and Golant's book we find chapter titles such as "Marx and Engels - the founders of the pedagogy of proletariat", "The fight of Clara Zetkin for the people's education", "Lenin's teaching on communist upbringing and school", and "Stalin's teaching on communist upbringing and school” (Gaņeļins, Golants, 1947).

Such use of the history of pedagogy for propaganda purposes is criticized by Depaepe (1993b). He points out that the use of the history of pedagogy for ideology in Eastern Europe and the West has not been without a cost to the field: "In the Western history of science there are for the taking countless examples of utilitarian and propagandistic use and abuse of educational history" (p. 7). An example is the limitation of the history of pedagogy to religious traditions: "In the Catholic tradition, here in Belgium, as elsewhere, there prevailed the conviction until deep in the 1950s that an historical excursion through the 'gallery of great masters' of education would inevitably lead to 'educational hero worship'. Something analogous is seen in the communist countries" (Depaepe, 1993c, p. 33).

Revisionism in the history of pedagogy and teacher training in the $1960 \mathrm{~s}-70 \mathrm{~s}$. The 1960s and the beginning of the 1970s is considered the "period of revisionism" both in general pedagogy and the history of pedagogy (Mahoney, 2000). Answers are sought to the following question: What and how should history be studied? Both historians of pedagogy and teacher trainers looked in the direction of social sciences. The "sociologization" of history of pedagogy began (Mergel, 1998). Tenorth, comparing traditional and "new" history of pedagogy writes that traditional history is the history of pedagogical illusions based on possibilities and influences. Social history acquaints one with the reality of education and upbringing (Böhme, Tenorth, 1990). Depaepe (2003), as a pioneer of the social-historical paradigm, mentions Brian Simon and his work Studies in the History of Education (1960-1991). Americans Bernard Bailyn and Lawrence A. Cremin (1925-1990) were also active in the field of revisionism. If earlier history of pedagogy focused on pupil-teacher relations, now pedagogical ideas and changes in practice were placed in broad social and political contexts and the history of ideas was replaced with the postulates of the social history of education (Depaepe, 2001, p. 632). The search for generalizations, free discussion about the problems of education, and de-mythologization of stories from the past, as well as the application of sociology methods and theories characterize the new history of pedagogy.

The history of pedagogy as a social science was enriched in topics, theories and methods. It "borrowed" from sociology theories on the relations between the individual and society and the socialization process, as well as quantitative research methods. However, Rüsen (1987) points out that this borrowing from the social sciences indicates the inferiority complex of historians of methodology, and 
he reminds us that history will never be as systematic as the social sciences.

Since the 1960s, the history of pedagogy has stopped confining itself to descriptions of particular periods of history and countries and the reconstruction of events. It has turned to the analysis and explanation of pedagogical and social phenomena in all their socio-cultural contexts, which results in revealing connections and theories. "Analytical" history researches vertically (Welskopp, 1998). Historians no longer specialize in a particular time period but in a phenomenon history stopped researching the time, but now researched the society. Such studies as "Socialization of childhood and youth", "School system and social structure", and "Professionalization of teachers' profession" emerged (Apel, 1996).

Were these changes reflected in teacher education programs, and if so, how? Almost all teacher education programs in the 1960s and 1970s included the history of pedagogy, which was taught as part of pedagogy/educational sciences. However, according to Campbell and Scherington (2002), the new history of pedagogy gave much to further the development of the science discipline, but it became less useful for teacher education programs (p. 56). The history of pedagogy as a subject considerably lagged behind in its development from the history of pedagogy as a science. The search for generalizations, free discussion about problems, and the phenomenological approach offered by the new history of pedagogy was more interesting than the old acts and facts. However, this required serious basic knowledge. Thus, the lecturers in teacher training programs had to choose either to continue teaching the basics of history of pedagogy according to the old system, or become "interesting" and modern and speak mainly about the problems of today through a historical perspective. This approach, however, risked that students without prior knowledge would not be able to be adequate partners in discussions.

Keeping to the old acts and facts history of pedagogy made it an unattractive subject; its necessity in teacher education was doubted. When characterizing the research of history of pedagogy in Belgium, de Vroede (1979) admits that the research of pedagogical phenomena in the universities from the empirically experimental point of view, and not the philosophical or historical, is more topical. He sees the future of history of pedagogy in revealing mutual connections between the development of society on the one hand, and upbringing and education on the other, which "would lead to a relevant social history of education" (p. 30).

At the University of Latvia, the history of pedagogy in the 1960s and 1970s was taught as part of the general pedagogy course, as it was done in other countries around the world. Professor Jānis Anspaks, a graduate of Latvia State Pedagogical Institute and doctor of pedagogical sciences, began teaching this course in 1956. In the early 1970s, he was joined by Ludvigs Grudulis (1921-2001), also a graduate 
of Latvia State pedagogical institute and a doctor of pedagogical sciences.

They used the pedagogy syllabi in which no more than 14 lines were devoted to the history of pedagogy (Metodiskie norādījumi..., 1963/64, Metodiskie ieteikumi..., 1970), as well as a textbook on the history of pedagogy of higher education institutions by Nikolai Konstantinov, Jevgenij Medinskij and Maria Shabayeva (1968), which was a translation from Russian into Latvian (Konstantinovs et al., 1968). During the Soviet period, not a single original work on world history of pedagogy was published by Latvian authors.

The history of pedagogy at the University of Leuven in the 1960s and 1970s was taught by Marcel Augustijn Nauwelaerts (1908-1983), and the two parts of the syllabus take up 265 pages (Nauwelaerts, 1968-1969). During this time in Belgium, the eighth edition of the historical pedagogy by Rombouts was published (Rombouts, 1962), as well as teacher education textbooks by De Wilde (1965) and Renaat Merecy (1966) on the world history of pedagogy.

The paradigm shift in the history of pedagogy in Soviet Latvia remained unseen. Firstly, this was due to the Iron Curtain and the resulting intellectual isolation from the Western world. Secondly, the social view of history in Soviet pedagogy was nothing new to students of pedagogy. One of the basic principles of MarxismLeninism, the class division approach, applied to every issue, including the history of pedagogy. This meant that all issues of pedagogy had to be treated in this political context, according to the activities of different social groups (classes). In the 1960s and 1970s, this requirement became even stricter: No individual countries are named in syllabi and books, and only the respective social system, based upon Marxist periodization of history, is mentioned. This can be seen in chapter titles such as "Upbringing in primeval society" (referred to Egypt and other ancient societies), "Upbringing, school and the emergence of the theory of pedagogy in slave society" (Sparta, Athens, and Rome), "Upbringing, school and the emergence of theory of pedagogy in feudal society" (the Middle Ages), and "Upbringing in the bourgeois society" (Germany, England, USA, etc.) (Konstantinovs et al., 1968; Metodiskie norādījumi..., 1963/64.). Depaepe (1998) writes, "The Marxist approach went a step further by making education responsible for the reproduction of social inequality." (p. 22)

Nauwelaerts' syllabus (1968-1969) also observes and strengthens the direction taken by his predecessors. Some parts of the syllabus are devoted to Christianity, where Jesus Christ and the church fathers as pedagogues (p. 92) are singled out, as well as the pedagogical movement of Catholics (p. iv). This trend is substantiated by the historiography of the history of pedagogy written by another history of pedagogy professor at the University of Leuven, Maurits De Vroede 
(1922-2002), published in 1977, in which the pedagogues are divided into "Catholic pedagogues" and the activities of the Catholic youth movement are singled out (De Vroede, 1979, p. 26-27).

Only one new topic in Nauwelaerts' syllabus testifies to new trends in the 1960 s - the "Upbringing of girls" (Nauwelaerts, 1968-1969, p.ii).

The "enlargement" of the world seems to be of interest in the study materials of both universities. Along with the traditional description of pedagogy in Germany, England and France, more attention than in previous years is given to pedagogy in the USA (in Gessler's syllabus it was not mentioned at all). Nauwelaerts' syllabus also mentions Austria, Switzerland, Italy, and Russia, and the books by Konstantinov, Medinskij and Shabayeva discuss pedagogy in socialist countries. A new chapter in the world history of pedagogy textbook by Konstantinov, Medinskij and Shabayeva is "The history of pedagogy of foreign countries", which differs from "General history of pedagogy" used in Ganjelin and Golant's book.

The message is clear - the world is divided into "ours" and the "others". The requirements of religious traditions, state and political parties turned out to be more powerful than the appeals by historians of pedagogy for a new history of education.

History of pedagogy in the 1990 s and the contemporary situation. Changes in global politics - the real and symbolic collapse of the Berlin wall and the Iron Curtain at the turn of the 1990s - influenced all spheres of social life, including the study process at university. New syllabi both in pedagogy and the history of pedagogy were created overnight at the University of Latvia. In the syllabus developed in 1991 (Autorprogramma..., 1991), half a printed page was devoted to the history of pedagogy. The first sub-chapter included the world history of education and pointed out several problems - the ideals of education in different times and countries, methods and means of education, and the formation of the first education systems. The second largest subchapter was devoted to the education experience in Latvia. The literature list included various, conceptually contradictory works: publications of the interwar period of independent Latvia, the previously mentioned Ganjelin and Golant book published in 1947, work by Russian historian of pedagogy, Alexandr Dzurinsky, published in 1989, and the revisionist study by Brian Simon Society and Education, in Russian, published in Moscow in 1989.

New breaths of air are also present in the syllabus of the history of pedagogy published by the University of Latvia in 1992, which takes up 35 pages (Anspaks, 1992). The changes mainly touched the persons to be studied - along with Anton Makarenko and Nadezhda Krupskaya, the list included Paul Natorp, John Dewey, Georg Kerschensteiner, Eduard Spranger and Lev Vygotsky, as well as the names 
of pedagogues from the period of independent Latvia, whose mention during the Soviet era was strictly forbidden.

Students at Leuven University at this time study from the syllabus and the textbook developed by d'Hoker and Depaepe that takes up more than 400 pages. A number of pedagogical problems are put forward in the chronological framework, including humans in space and time, the ideal of education and practice, changes in pedagogic mentality, pedagogic optimism and pessimism, evolution of children's toys and books, pedagogization of children's lives and world, development of pedagogic reality in the family, and emancipation of women (D'Hoker, 1993; Depaepe, 1993a).

Judging by the topicality of social problems of pedagogy, revisionism of the history of pedagogy during the 1960s finally reached universities and teacher education programs in the 1990s. However, comparison of the syllabi of both universities reveals that both the richness of topics and the scope of the field of study of the history of pedagogy is considerably narrower in Latvia than in Belgium. Thus, if until the 1970s it was mainly the scope of the material on the history of pedagogy and the cultural context that differed in the universities, then by the 1990s Belgium had left Latvia behind both in topicality and diversity of topics. It can be stated that the approach to the history of pedagogy in Belgium is more profound, solid and interesting. Evidently, the main reason for this inequality is an earlier recognition of the new history of pedagogy in the universities of Belgium, while the new understanding only reached Latvia in 1991 when it regained national independence.

Though the concept of the new history of pedagogy, thanks to the cooperation of historians of pedagogy in Belgium, the USA and Germany, is known, its introduction into teacher education programs is slow. The most important achievements are the development of new study courses: Teacher's image: past experience and today's topicalities (Ķestere, Kalı̧e, 2009) and History sources in pedagogical research (Kalke, Kestere, 2010), as well as the introduction of such topics as "The history of childhood" and "Descriptions of pedagogy in a totalitarian and democratic country" in the general history of pedagogy (Krūze, 2010, Kaḷķe, 2009). The new history of pedagogy is more widely represented in the pedagogy doctoral study program and doctoral theses written at the University of Latvia.

Research into the history of pedagogy in Latvia is mainly directed towards studies of national history; this is logically connected with the available sources and current interests in the field of national education. However, it is important to make research of national history accessible and understandable to the international audience by relating it to common global issues: ,....in so far as we continue to write national histories, we are now obligated as never before to write them in a form which is intelligible and accessible to a wider global audience" (Lowe, 
2002, p.498). Using theories of philosophy, sociology and pedagogy, as well as the comparative approach in the interpretation of the facts, the national history of pedagogy of Latvia could become interesting to the global audience.

Latvian historians of pedagogy enter the global stage mainly with Soviet experience that is used to exemplify the influence of political power on education and identify the trends of totalitarianism in education (Ķestere, Krūze, 2013). The second major research topic of the history of pedagogy in Latvia is the formation of pedagogy as a science (Krūze, Ozola, 2013; Ķestere, Ozola, 2011). This has become topical throughout the world in the last 20 years, since the field of pedagogy, as a science, has expanded considerably and became more diverse, putting forward a number of questions about the identity of this branch of science. Research in this direction helps understand the nature of pedagogy and education sciences, as well as the trends of education sciences today.

The history of pedagogy, like the history of any science, starts with the knowledge of facts. However, facts are not yet history. For the interpretation of facts and their explanation, modern historians of pedagogy most frequently use the theories of philosophers and sociologists, such as Michel Foucault (1926-1984), Pierre Bourdieu (1930-2002) and Bruno Latour, who are known also in Latvia.

\section{Conclusions}

It has been acknowledged that until the second half of the $20^{\text {th }}$ century, the history of pedagogy served mainly utilitarian aims. Its objective was to inspire future teachers through past experience, by inundating the general pedagogy course with ideas and concepts. The courses and textbooks were overloaded with acts and facts. The history of pedagogy in Soviet Latvia consolidated around Marxism ideology and in Leuven University around values preached by the Catholic Church. A period of revisionism started in the democratic world in the 1960s - research field and methods were broadened and enriched under the influence of social sciences. However, these changes did not reach Latvia that was living behind the Iron Curtain in the Soviet Union. As a result, as comparison with Leuven University reveals, the development of the history of pedagogy was underdeveloped, and Latvia was left behind democratic countries.

However, in recent years, Latvian researchers have gradually joined the global society in which the objective of the history of education is not a self-aimed reconstruction of the past, but a discussion about significant social problems applying history for their understanding and explanation. We believe, that the most important objective of the teaching of the history of pedagogy today is to explain topical problems in the field of education using the methodology of the history. 
However, we should not provide concrete or practical recommendations on how to solve them.

Historical experience also serves as a means for creation and evaluation of new ideas. Nevertheless, it is important to remember that the duty of the past is not to confirm the correctness of today's views: The history of pedagogy should be viewed in its entirety without pulling out individual facts in order to confirm some considerations of today. The history of pedagogy should not serve for the legitimization of some pedagogical theory or system.

We are deeply convinced that modern, problem-based research into the history of pedagogy enriches the teacher education curriculum with reflections and considerations about significant issues and phenomenon in the field of education and society as a whole.

\author{
Received 20131002 \\ Approved for publishing 20140214
}

\title{
References
}

Anspaks, J. (1998). Milda Drīzule. Pedagoǵiskā doma Latvijā no 1940.gada līdz mūsu dienām (redaktors A. Staris). Rīga: Puse, 38-40.lpp.

Anspaks, J. (sast.) (1992). Darba programma pedagoǵijas vēsturē. Rīga: Latvijas Universitāte.

Apel, H. J. (1996). Historiche Methoden. Taschenbuch der Pädagogik, Bd. 2: 603-616. Baltmannsweiler.

Autorprogramma kursam „Pedagogíija”. (1991). LU Pedagoǵijas vēstures muzejs.

Beales, A. C. F. (1989). The Place of the History of Education in the Training of Teachers. History of Education: The Making of a Discipline (edited by P. Gordon, R. Szreter). The Woburn Press, p. 131-142.

Böhme, G., Tenorth, H. E. (1990). Einfürung in die Historische Pädagogik. Darmstadt: Wissenschaftliche Buchgesellschaft.

Campbell, C., Sherington, G. (2002). The History of Education: The possibility of survival. Change: Transformations in Education, vol. 5 (1): 46-64.

Coetzer, I. A. (1993). Grounding and development of History of Education in the RSA and in Europe, especially the Netherlands and Belgium. History of Education: a ten contemporary educational issues (edited by I. A. Coetzer, A. E. Van Zyl). Pretoria: University of South Africa, p. 1-22.

Crook, D., McCulloch, G. (2002). Introduction: Comparative approaches to the history of education. History of Education, vol. 31 (5), no. 5: 397-400.

D’Hoker, M. (1993). Historische pedagogiek. Deel 1: Van de Oudheid tot de Aufklärung. Leuven: Acco.

De Vroede, M. (1979). Das Fach „pädagogische Historiographie” in Belgien seit 1954. Die historische Pädagogik in Europa und den U.S.A. Berichte über die historische Bildungsforschung, Teil 1 : Belgien, Finnland, Frankreich, Gross-Britannien, Italien, Niederlände, Norwegen, Oesterreich, Polen, U.S.A. Veröffentlichungen der Historischen Kommission der Deutschen Gesellschaft für Erziehungswissenschaft (Herausgeber M. Heinemann), Bd. 3.1, S. 11-42. Stuttgart: Klett-Cotta.

De Wilde, P. (1965). Geschiedenis van de Pedagogiek. Deel I-II. 4e ongewijzige druk. Antwerpen, Gent, Leuven, Brussel, Kortrijk: Standaard wetenschappelijke uitgeverij.

Depaepe, M. (1993a). Historische pedagogiek. Deel 2: Van de Aufklärung tot Heden. Leuven: Acco.

Depaepe, M. (1993b). History of education anno 1992: 'A tale told by an idiot, full of sound and fury, signifying nothing'? History of Education, vol. 22 (1), no. 1: 1-10.

Depaepe, M. (1993c). Some statements about the nature of the history of education. Why should we teach history of education? (Edited by K. Salimova E. V. Johanningmeier). Moscow: The Library of International Academy of Self-Improvement, p. 31-36. 


\section{DEVELOPMENT OF HISTORY OF EDUCATION IN THE CONTEXT OF TEACHER ...}

Depaepe, M. (1998). Educationalization: a key concept in understanding the Basic process in the history of Western education. History of Education Review, vol. 27 (1): 16-28.

Depaepe, M. (2001). A Professionally Relevant History of Education for Teachers: Does it Exist? Reply to Jurgen Herbst's State of the Art Article. Paedagogica Historica, vol. 37 (3): 631-640.

Depaepe, M. (2003). What Kind of History of Education May We Expect for the Twenty - first Century? Some Comments on Four Recent Readers in the Field. Paedagogica Historica, vol. 39 (1\&2): 187-199.

Depaepe, M. (2008). Nenozīmības īpatnības. Pedagoǵijas vēsture skolotāju izglītībā. ATEE Spring University. Teacher of the 21st Century: Quality Education for Quality Teaching. Latvijas Universitāte, p. 14-24.

Depaepe, M. (2012). The Ten Commandments of Good Practices in History of Education Research. Between Educationalization and Appropriation (edited by M. Depaepe). Leuven University Press, p. 463-469.

Falbork, G., Cjarnolusky, V. (red.) (1901). Ucjitelskije seminariji I skoli. S-Pterburg: B. M. Volf.

Gaṇel̦ins, ŠS. I., Golants, J. J. (1947). Pedagogíijas vēsture. Mācību grāmata pedagoǵiskām mācību iestādēm. Rīga: Latvijas Valsts izdevniecība.

Gessler, J. (1948). Historische pedagogiek. Leuven: N.V. De Vlaamse drukkerij.

Haupt, H. G., Kocka, J. (2004). Comparative History: Methods, Aims, Problems. Comparison and History: Europe in Cross-National Perspective (edited by D. Cohen, M. O’Connor). New York: Routledge, p. 23-39.

Kalı̧, B, B. (2009). Pedagogijas vēsture. Available at: http://estudijas.lu.lv/enrol/index.php?id=3226

Kalı̧,ke, B., Ķestere, I. (2010). Vēstures avoti pedagoǵijas pētniecībā. Available at: http://estudijas.lu.lv/course/ info.php?id=3225

Katholieke Universiteit te Leuven. Syllabus of Handleiding bij den cursus in de historische paedagogiek ten behoeve en tot gemak van zijne toehoorders opgesteld door Prof. Dr. Jan Gessler. Academisch jaar 1934-35. Bij Val. Wijnants, L. Schreursvest, 15, Leuven.

Ķestere I., Ozola, I. (2011). Pedagogy: A Discipline under Diverse Appellations. Baltic Journal of European Studies, vol. 1, no. 1(9): 306-321.

Ķestere, I. (2007). LU profesors Jānis Kauliņš (1863-1940) un viņa laikabiedri. Latvijas Universitātes raksti. Zinātñu vēsture un muzejniecība. 716.sēj. (redaktors I. Vilks). Rīga: Latvijas Universitāte, 53.-62.lpp.

Ķestere, I., Kaḷke, B. (2009). Skolotāja tēls: pagātnes pieredze un mūsdienu aktualitātes. Available at: http://estudijas.lu.lv/course/info.php?id=3308

Ķestere, I., Krūze, A. (eds.) (2013). History of Pedagogy and Educational Sciences in the Baltic Countries from 1940 to 1990: An Overview. Riga: RaKa.

Konstantinovs, N., Medinskis, J., Šabajeva, M. (1968). Pedagogijas vēsture. Mācību grāmata augstākajām pedagogiskajām mācību iestādēm. Rīga: Zvaigzne.

Krūze, A. (2010). Pedagoǵijas ideju attīstība pasaulē un Latvijā. Available at: http://estudijas.lu.lv/course/info. php?id $=705$

Krūze, A., Ozola, I. (2013). Pedagogy as a Science in Latvia. History of Pedagogy and Educational Sciences in the Baltic Countries from 1940 to 1990: An Overview (edited by I. Kestere, A. Krūze). Riga: RaKa, p. 234-242.

Latvijas Universitāte divdesmit gados. 1919-1939. I daļa: Vēsturiskas un statistiskas ziņas par universitāti un tās fakultātēm (1939). Rīga: Latvijas Universitāte.

Lehrplan für das Parochiallehrer-Seminar zu Walk, Riga den 7 Mai 1879. (1879). Riga: Alex Stahl.

Lowe, R. (2002). Do we still need history of education: is it central or peripheral? History of Education, vol. 31 (6), p. 491-504.

LVVA, 7427. f., 13. apr., 719.1.

LVVA, 7427.f., 13.apr., 788.1.

LVVA, 7427.f., 6.apr., 63.1.

M.A.N. (1977). Gessler, Jan Baptist. Standaard encyclopedie voor opvoeding en onderwijs. II. Antwerpen: Standaard uitgeverij, Hoorn: Uitgeverij Kinheim, pg.176.

Mahoney, K. A. (2000). New Times, New Questions. Educational Researcher, vol. 29 (8), p. 18-19.

Mercey, R. (1966). Historiche pedagogiek. Schiets van ideeen en werkelijkheiden Hellas tot Heden. Antwerpen: De Sikkel.

Mergel, T. (1998). Geschichte und Soziologie. Geschichte. Ein Grundkurs (Herausgeber H. J. Goertz). Rowohlts Enzyklopädie, S. 621-651.

Metodiskie ieteikumi pedagogijas kursa studēšanai. (1970). Rīga: Ar Darba Sarkanā Karoga ordeni apbalvotā P. Stučkas Latvijas Valsts Univsersitāte, Pedagogijas un psihologijas katedra. 
Metodiskie norādījumi pedagogijas kursa studēšanai (1963/64.m.g.). P. Stučkas Latvijas Valsts universitāte, Pedagoǵijas un psihologijas katedra.

Nauwelaerts, M. A. (1968-69). Opvoeding en ondervijs in het verleden. Historisch overzicht. Deel 1-2. LeuvenNederlands: Acco-uitgeven.

Obšteins, K. (1929, 1930). Pedagogijas vēsture. 1-2.sēj. Rīga: Valtera un Rapas grāmatspiestuve.

Obšteins, K. (1932, 1939). Pedagogijas vēsture. 3-4.sēj. Rīga: Latvijas Vidusskolu skolotāju kooperatīvs.

Richardson, W. (1999). Historians and educationists: the history of education as a field of study in post-war England. History of Education, no. 28 (1): 1-30.

Rombouts, Fr. S. (1929). Leerboek der historiese pedagogiek. Met 104 portretten. Amsterdam, Antwerpen.

Rombouts, Fr. S. (1948). Leerboek historische pedagogiek. Vierde druk. Met 73 portreten. Tilburg: Drukerij van het R. K. Jongensweeshuis.

Rombouts, Fr. S. (1962). Historische pedagogiek. Achtste druk met 73 portreten. Tilburg: Zwijsen.

Rüsen, J. (1987). Narrativität in der Geschichtswissenschaft. Theorie der modernen Geschichtsschreibung (Herausgeber P. Rossi). Frankfurt am Main: Suhrkamp, S. 230-237.

Schütze, F. W. (1876). Evangelische Schulkunde. Praktische Erziehungs und Unterrichtslehre für Seminare und Volksschullehrer. Leipzig: Druck und Werlag von B. E. Teubner.

Seiľ̦̌, V. (1943). Paidagogikas vēsture. I dal̦a. Daugavpils: Vl. Loča izdevniecība.

Tomāss, E. (Red.) (1940). Baltijas skolotāju seminārs. 1870-1919. Rīga: Bij. Baltijas skolot. sem. audzēkṇu un skolot. b-bas izd.

Tyack, D. B. (1976). The History of Education and the Preparation of Teachers: A Reappraisal. Understanding History of Education (edited by R. R. Scherman, J. Kirschner). Cambridge, Massachusetts: Schenkman publ. comp., INC.

Verheyen, J. E. (1939). Gessler Jan. Verneyen en Casimir. Paedagogische enciklopaedie. I. Antwerpen: De Sikkel, pg. 543-544.

Welskopp, T. (1998). Erklären. Geschichte. Ein Grundkurs (Herausgeber H. J. Goertz). Rowohlts Enzyklopädie, S. $132-168$. 